\title{
Rimljaninu ništa nije smeće - pogotovo ne hrana
}

\author{
Ivana Ožanić Roguljić
}

DOI: $10.17234 / 9789531757232-13$

Potrošnja hrane nije se mnogo promijenila tijekom duge povijesti čovječanstva, barem u terminima kalorija. Iako su unutar širokog geografskog područja kao što je Rimsko Carstvo razlike u prehrani bile velike, u slučaju rimske civilizacije možemo pretpostaviti dnevnu prosječnu potrošnju od dvije do tri tisuće kalorija (Forni \& Marcone 2002). Najveća promjena u odnosu prema hrani i živežnim namirnicama vidi se u načinima kako se hrana pripremala, čuvala, dorađivala te ponovno stavljala na stol. Rimljani su na pametan i efikasan način koristili i ponovno koristili svako sredstvo ili ideju na koju su naišli. Od građevinskog materijala do posuđa te od oruđa i oružja do umjetnosti. Posebno je to vidljivo u pripremi hrane, osobito mesa. Životinje su osim kao izvor hrane bile tretirane i kao izvor sirovine (kost, koža) ili goriva (mast). Načini na koje su Rimljani reciklirali ili ponovno koristili resurse, neke su od glavnih karakteristika rimske civilizacije.

U Apicijevoj kuharici prva je knjiga posvećena upravo konzerviranju, spašavanju pa čak i ponovnoj upotrebi ili bolje rečeno, krivotvorenju, različite hrane i napitaka. Možda je najizravniji primjer takve prakse savjet kako od crnog vina napraviti bijelo (Apicius I.4.). Naime, u crno vino se doda brašno od boba ili tri bjelanjka i trese se što duže. Sutradan će vino biti bijelo. To se može napraviti i koristeći pepeo od loze bijelog grožđa. Prema Apiciju liburnsko ulje je očito bilo cjenjenije od hispanskog te savjetuje da se u hispansko ulje dodaju dobro usitnjeni začini, pečenu i usitnjenu sol te najmanje tri dana ostavi da odstoji, uz povremeno miješanje. Navodno, nitko neće primijetiti da to nije liburnsko ulje (Apicius I.5.).

Tumačenje potrebe da se krivotvori liburnijsko ulje možda stoji u činjenici da se hispansko ulje proizvodilo u daleko većim količinama nego što su mogli dati liburnski maslinici. Osim toga, o uvozu maslinovoga ulja iz Hispanije imamo mnoštvo dokaza u velikoj količini ambalaže, poglavito okruglastih i glomaznih amfora Dressel 20 koje su, nakon što bi ulje bilo iskorišteno (možda ponekad zaista bilo i pretvoreno u „liburnsko“), bile sekundarno upotrijebljene. Mogle su poslužiti kao ambalaža novom proizvodu, a i kao građevinski materijal (Abdelhamid 2016: 95). Bila je uobičajena praksa da se većina raznih oblika ispražnjenih amfora, osim što su bile ponovno upotrijebljene za nove proizvode, često iskoristi kao drenaža (Pula, Crikvenica) ili za potrebe grobnih konstrukcija (ukop u amfori). Na primjer, amfore Dressel 20 zajedno s afričkim amforama korištene su čak i za utemeljenje obale (sl. 1), odnosno formiranje manipulativnog prostora na obali na lokalitetima Spinut i Trstenik (Cambi 1980: 73-80; 1983, 363-381; Radić Rossi 2008: 500-501; Radić Rossi 2009). 
Ponovna upotreba amfora danas se može vidjeti i s pomoću modernih tehnologija npr. amfore Dressel 2-4 uobičajeno su smatrane amforama za vino. U novije vrijeme prvi put su napravljene analize organskih ostataka za ovaj tip amfore. Analizirane su amfore s lokaliteta Oplontis (Italija) koje su pokazale da su amfore zaista sadržavale vino, no i da su bile više puta upotrebljavane za istu svrhu (Pecci et al. 2017: 515-521). Amfore korištene za vino ili ulje često su naknadno poslužile i za transport voća kao što su šljive, breskve i višnje, ali i npr. lješnjaka (Peña 2016; Abdelhamid 2016: 95). Vrlo je vjerojatno da amfore koje su prvobitno sadržavale izuzetno aromatični rimski tekući začin načinjen od fermentirane ribe i soli (garum, liquamen) nisu bile korištene za druge vrste namirnica zbog mirisa koji su posude morale upiti u svoje stijenke. Ali, postoje podaci o amforama za ulje u kojima se naknadno prenosio garum ili usoljene sardine (Auriemma 2000: 30). Da se liquamen mogao pokvariti bez obzira na količinu soli kojom se pripremao saznajemo kod Apicija koji opet daje savjete kako ga popraviti. Ukoliko je počeo neugodno smrdjeti izvrnula bi se prazna posuda (vjerojatno keramička), nadimila lovorom i čempresom, provjetrila se i u nju se potom ulio liquamen. Ako se liquamen previše usolio spašavao se vrčem meda ili mladim moštom (Apicius I.VII).

U pripremi hrane i namirnica amfore su često bile pomoćno sredstvo. Kod Katona je sačuvan savjet koji glasi: ako trebamo izbijeljenu sol, najbolje je upotrijebiti čistu amforu kojoj je razbijen vrat te se u nju ulije voda, potom bi se u košaru stavila obična sol i uz miješanje se sve izlagalo suncu te se na taj način dobila sol dovoljno dobra za sušenje mesa ili usoljavanje ribe (Cato 88).

Med se često koristio u konzervaciji mesa, voća i povrća, ponekad sam, a ponekad u kombinaciji sa solju ili drugim začinima (Apicius I. 8, 9, 14, 20, 24 ). No i med se mogao pokvariti, a to bi se desilo najčešće ako se pčelama oduzeo nesazrio med ili je on eventualno bio izložen nepovoljnim prilikama. Apicije kaže da se loš med može prepoznati tako da u njega staviš fitilj, ako gori, dobar je, ako ne gori - nije. ${ }^{1}$ Postoji i spas tako da se u ambalažu doda jedan dio lošeg i dva dijela dobrog meda te ga tako prirediš za prodaju (Apicius I. 15, 16). Usprkos potrebi za ekonomičnosti, neku hranu nisu kuhali u starim loncima i zdjelama, a Apicije na više mjesta u svojim receptima naglašava da je za kuhanje grahorica ili žitarica potrebno upotrijebiti novi lonac (accipies caccabum novum). Najvjerojatnije bi takve namirnice često zagorjele u keramičkim posudama (Apicius V. 2; 4.2; IX.8,1). Prema Varonu znamo da grahorice koje treba čuvati dulje vrijeme, treba pospremiti u keramičku posudu u kojoj je bilo ulje, prekriti sadržaj pepelom i zatvoriti (Varro I, 58).

Za jelo se pripremalo apsolutno svaku jestivu životinju, bilo da je bila riječ o mesu koje je i danas uobičajeno u pripremi ili vrstama koje su potpuno egzotične, a danas najčešće pripadaju ugroženim i zaštićenim životinjama. Jele su se gotovo sve vrste ptica, bilo da je riječ o kokoši, guski, noju, plamencu, ždralu, paunu, fazanu, drozdu ili nekoj ptici pjevici (Apicius VI). Od životinja koje su davale veću količinu mesa, svinja je bila najpopularnija. Imala je nekoliko imena; Sus, porcus, porca i aper. Bilo je pedeset različitih načina kuhanja svinjetine, kao i šest vrsta kobasica na bazi svinjetine. U vjerskoj ceremoniji suovetauralia (sus + ovis + taurus) svinja je imala prvo mjesto. Za prehranu se koristilo meso i svinjska jetra, rodnica, vime, želudac, rep i papak (Apicius, VII, I 1-5, VII, 3, 1-2; VII, 7, 1-2). Meso i iznutrice se sjeckalo, miješalo s drugim mesom pa čak i ribom od čega se radilo jelo patina koje je dobilo naziv po zdjeli u kojoj je pripremljeno (Apicius, IV, 2, 14-15; Dalby \& Grainger 1996: 136). Svinjska mast (laridum) koristila se umjesto maslinovog ulja (Davies 1971: 124; Junkelmann 1997: 163). Po svemu zaključujemo da je gotovo svaki dio svinje bio iskorišten u prehrambene svrhe, a kosti i koža su se prerađivali u druge svrhe. Isto je tako bilo i s drugim životinjama. Rimljani su rijetko jeli

\footnotetext{
${ }^{1}$ A. Kudelić i autorica ovog pisanog priloga pokušale su izbijeliti crno vino bjelanjkom, međutim, to im nije uspjelo. Također se pokušalo upaliti fitilj u medu od kestena, no fitilj je gorio vrlo kratko, a možda je i med bio stvarno loš.
} 
govedinu. Bio je to znak luksuza koji se konzumirao samo u posebnim prilikama. Kada je krava bila žrtvovana bogovima, srce, jetra i pluća bi se dali svećenicima, s određenim dijelovima koje su palili na oltaru. Govedina se rijetko jela zbog svoje veličine jer bi samo najhladnije vrijeme moglo omogućiti da ona ostane svježa. Krave su obično korištene za dobivanje mlijeka, a ne za konzumaciju.

Mora se, naravno, istaknuti da se ishrana razlikovala prema socijalnom statusu Rimljanina. Smatra se da su kućni robovi imali bolju ishranu od siromašnih Rimljana jer su mogli uvijek računati barem na ostatke obroka od svojih gospodara, ukoliko se u domaćinstvu nije posebno kuhalo za njih (Harper 2011: 105).

Često se zna reći da je danas odnos prema hrani promijenjen zbog nedostatka osjećaja poštovanja i vrijednosti prema cijelom procesu proizvodnje, porijeklu i identitetu namirnica (Schneider 2011). Da nisu niti svi Rimljani bili jednako osviješteni o vrijednosti namirnica te nehajan stav bogatijih rimskih slojeva prema hrani vidljiv je u umjetnosti. Asaraton oikos ili nepometeni pod naziv je za mozaik pronađen u Akvileji, Rimu i nekim drugim lokalitetima, a nalazio se u trikliniju, tj. blagovaonici (2. st.), a prema Pliniju prvi takav izrađen je u Pergamu (Plinius, Naturalis Historia, 36.184). Na mozaiku je prikazano kako su uobičajeno izgledale rimske blagovaonice nakon velikih večernjih gozbi po kojima su Rimljani bili poznati. Na podu su prikazani pojedeni ostaci riba, školjaka, piletine, oraha, rakova, ježeva, voća i ostalog što se pomelo nakon završetka gozbe.

Premda se prema arheološkim podacima i podacima iz izvora čini da su Rimljani generalno zaista imali ekonomičan stav prema otpadu, poglavito hrani, ipak su izazvali nekoliko ekoloških katastrofa, a neke biljke su doveli do potpunog nestanka. Najpoznatiji primjer je biljka laserpicium, koju Grci zovu silphium. Umak od silphiona zvao se laser i smatralo ga se univerzalnim lijekom i afrodizijakom, a njegova težinska vrijednost bila je jednaka vrijednosti u srebrnim denarima. Prema Pliniju posljednji silphion iz Kirenaike pojeo je car Neron i nakon toga potpuno nestao jer su njegovo prirodno stanište zamijenile njive i oranice (Plinius, Naturalis Historia, 19.38-39). Čak su i izvori zabilježili snažan utjecaj razvijenog gospodarstva, poljoprivrede i intenzivne obrade tla na krajolik te se navodi da su se šume povukle pred njivama, vinogradima, maslinicima i voćnjacima i na taj način sasvim sigurno promijenili klimu pojedinih područja (Lucretius, De rerum natura, 5.1370-1378).

Urbanizacija, poljoprivreda, trgovina, komunikacije i svi aspekti rimskog načina života imali su glavnu karakteristiku, a to je praktičnost. Takav je stav bio i prema namirnicama i hrani koja se na kvalitetan način prenosila, pohranjivala, pripremala i posluživala, a ako je bilo potrebno ponovo upotrijebila kao nešto sasvim drugo.

Primjeri dani u ovom kratkom pregledu pretežno se odnose na razdoblje Rimskoga Carstva od 1. do 2. st. Na prvi pogled moglo bi se reći da su bogatiji slojevi bili rastrošni, a da su siromašni čuvali svaku sitnicu, ali zapravo organizacija ponovne upotrebe raznih proizvoda i njihove ambalaže morala je imati veliku logističku potporu i zahvaćala je svaki dio društva. Priprema (čišćenje, punjenje) amfora za ponovnu upotrebu mogla se odvijati u kućanstvu ili na velikim gospodarskim postrojenjima. Isto tako popravljanje meda ili ulja moglo se raditi za daljnju prodaju ili u smočnici domaćinstva. Karakteristika rimskog razdoblja jest visoki standard i raznolikost prehrambenih proizvoda koja je nastala zahvaljujući visokoj razini organiziranosti gospodarstva u kojem je i ponovna upotreba sasvim sigurno imala svoj udio. 


\section{Literatura}

Abdelhamid, S. 2016. Against the throw-away-mentality. The reuse of amphoras in ancient maritime transport. U: Mobility, Meaning and the Transformations of Things (ur. H. P. Hahn, H. Weiss), Oxbow Books. Oxford. 91-106.

Auriemma, R. 2000. Le anfore del relitto di Grado e il loro contenuto. Mélanges de l'Ecole française de Rome. Antiquité 112. Rim. 27-51.

Cambi, N. 1989. Anfore romane in Dalmazia. Actes du colloque de Sienne (22-24 mai 1986). Sienne. 311-337.

Dalby, A. \& Grainger, S. 1996. The classical cookbook. Getty Publications. London.

Davis, R.W. 1971. The Roman military diet. Britannia 11. Cambridge. 122-42.

Forni, G. \& Marcone, A. (ur.) 2002. Storia dell'agricoltura italiana. I. Polistampa. Firenze.

Harper, K. 2011. Slavery in the Late Roman World, AD 275-425. Cambridge University Press. Cambridge.

Junkelmann, M. 1997. Panis militaris, P. von Zabern, Mainz, 1997.

Pecci, A., Clarke, J., Thomas, M., Muslin, J., van der Graaff, I., Toniolo, L., Miriello, D., Crisci, G. M., Buonincontri, M., Pasquale, G. Di. 2017. Use and reuse of amphorae. Wine residues in Dressel 2-4 amphorae from Oplontis Villa B (Torre Annunziata, Italy). Journal of Archaeological Science: Reports $12,515-521$.

Peña, J. T. 2016. The reuse of transport amphoras as packaging containers in the Roman world: an overview. U: Roman amphora contents: reflecting on maritime trade of foodstuffs in antiquity. Roman and late antique Mediterranean pottery 9. http://resromanae.berkeley.edu/sites/default/files/PENA\%20SUBMITTED\%202016A\%20PREPUBLICATION\%20MS.pdf

Radić Rossi, I. 2008. Podmorsko arheološko nalazište u predjelu Spinut u Splitu. Kulturna baština 34. Split. 351-372

Radić Rossi, I. 2009. Arheološka baština u podmorju Kaštelanskog zaljeva. Archaeologia Adriatica 2. Zadar. 489-506

Schneider, F. 2011. The History of Food Wastage. 3rd international Conference "Waste - The Social Context", Edmonton, Alberta, May 08-11, 2011. U: Edmonton Waste Management Center of Excellence. "Waste - The Social Context" Conference. 2011 Proceedings. http://www.ewmce. com/library/2011-conference-proceedings, 11.8.2017. 


\section{Izvori}

Marcus Gavius Apicius, De Re Coquinaria, Slapšak S., Apicije o kuvanju, Zagreb, 1989.

Gaius Plinius Secundus, Naturalis Historiae, In: Humphrey, J. W. et all. Greek and Roman Technology: A Sourcebook : Annotated Translations of Greek and Latin Texts and Documents, New York 1999.

Marcus Portius Cato, U: H. Fairfax, Roman farm management; the treatises of Cato and Varro done into English, with notes of modern instances by a Virginia farmer, New York 1918.

Marcus Terentius Varro, U: H. Fairfax, Roman farm management; the treatises of Cato and Varro done into English, with notes of modern instances by a Virginia farmer, New York 1918.

Titus Lucretius Carrus, De rerum natura, U: Humphrey, J. W. et all. Greek and Roman Technology: A Sourcebook: Annotated Translations of Greek and Latin Texts and Documents, New York 1999. 